\title{
The Ability of Lactobacillus plantarum Bacteria to Denaturate Goat Skin in Producing Gelatin with Different Goat Ages and Fermentation Times
}

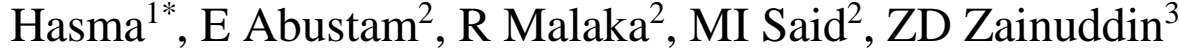 \\ ${ }^{1}$ Biology Education Study Program of STKIP YAPTI Jeneponto, Jl. M. Ali Dg Gassing No 1 Binamu, Jeneponto \\ 92311 \\ ${ }^{2}$ Department of Animal Production, Faculty of Animal Science, Hasanuddin University \\ ${ }^{3}$ Department of Biology, Faculty of Mathematics and Natural Science, Hasanuddin University \\ *Corresponding Author Email : hasmasona@gmail.com and hasmajepot@yahoo.co.id
}

\begin{abstract}
Goat skin is rich in protein compounds such as collagen, but it is highly bound to calcium minerals which have the potential to be processed into gelatin, so that for the denaturation process of skin proteins, fermented using $L$. plantarum. Curing stage on goat skin using chemical acid has done a lot, but using biologycal acid with Lactic Acid Bacteria (LAB) Lactobacillus plantarum is still very rare. The presence of lactic acid levels produced by BAL L. plantarum on MRS-Broth media that has been added to goat skin ensures that L. plantarum BAL bacteria can grow well. This research is the initial information to determine the ability of L. plantarum bacteria to grow on goat skin with indicators of bacterial population, lactic acid production, $\mathrm{pH}$ and total dissolved protein with different goat ages and fermentation times. This study uses a completely randomized design (CRD) factorial pattern $3 \times 3$ by treating the age factor of goats ( 1 year, 2 years and 3 years) and the fermentation time factor (24 hours, 48 hours and 72 hours). L. plantarum bacteria are isolated from milkfish, male goat skin Ettawah Breeds (PE) obtained from the same farm. Each treatment was repeated 4 times. The results showed that the bacterial population experienced rapid growth and a significant increase in the fermentation duration of 24 hours, 48 hours to 72 hours, the number of cells ranged from $8.50 \pm 0.45 \log _{10} \mathrm{CFU} / \mathrm{mL}, 8.81 \pm 0.41 \log _{10} \mathrm{CFU} / \mathrm{mL}$. $9.34 \pm 0.70 \log _{10} \mathrm{CFU} / \mathrm{mL}$. From this result, the duration of fermentation is 72 hours at most. Likewise, lactic acid production experienced a significant increase in the 24-hour fermentation duration to 72 hours starting from $1.03 \pm 0.17 \%-1.05 \pm 0.04 \%$. $\mathrm{pH}$ at 1 year of age $5.44 \pm 0.37$ tended to be acidic compared to 2 years and 3 years $(5.60 \pm 0.16$ and $5.60 \pm 0.26)$ which showed the age of 1 year was the highest acidity. Total dissolved protein showed a significant effect on the age of the goat and the duration of fermentation, the longer the fermentation ( 72 hours), the more dissolved protein $(8.80 \% \mathrm{~g} / \mathrm{mL} \pm 0.66 \% \mathrm{~g} / \mathrm{mL})$, the lower the age of the goat, the more goat protein dissolved high (1 year) $(8.57 \% \pm 0.97 \% \mathrm{~g} / \mathrm{mL}$ ). The most effective growth ability of L. plantarum was obtained at 72 hours fermentation and 1 year old goats showed better quality than skin 1 and 2 years to be used as curing material in gelatin making.
\end{abstract}

Keywords: Lactobacillus plantarum, gelatin, fermentation.

\section{INTRODUCTION}

Goat skin consists of $64 \%$ water, $33 \%$ protein, $0.5 \%$ mineral salt, $2 \%$ fat and other $0.5 \%$ constituents such as vitamins and pigments. The most important component of skin composition is protein, especially collagen protein. Skin protein consists of collagen, globulin, keratin, elastin, albumin, and mucin proteins. This collagen protein will be used for gelatin production[19].

Goat skin is rich in protein compounds such as collagen, bound strongly with calcium minerals that have the potential to be processed into gelatin [22]. Goat skin has a thick and hard fur texture and a characteristic odor that is underutilized so that processing goat skin waste into gelatin can increase added value and reduce waste pollution.

One important step in the gelatin production process which is the main ingredient in the formation of biopolymers is the curing process. The quality and quantity of gelatin products is highly determined in the curing process [19]. The denaturation or curing process is in principle the initial chemical reaction process of the collagen skin 
connective tissue in the curing material either by using curing material from acids, bases or enzymes. The denaturation process is the process of terminating the amino acid double bonds partially causing the structure of intermolecular and intramolecular bonds in the skin collagen protein to weaken[9].

The use of chemical acid curing materials such as $\mathrm{HCl}, \mathrm{H}_{2} \mathrm{SO}_{4}[1]$ and $\mathrm{Ca}_{3} \mathrm{COOH}$ on goat skin [18] has been widely used but using biologycal acids with the use of $L$ plantarum suspension is still very rare. This research is important in the early stages of identifying the ability to grow $L$ plantarum bacteria and lactic acid levels produced on goat skin with different ages and fermentation times.

L. plantarum is a type of lactic acid homofermentative bacteria, aerobic or facultative anaerobic, has negative catalase, is able to melt gelatin, is tolerant of acid, quickly digests protein, does not reduce nitric acid, and is able to produce lactic acid and is known as lactic acid forming bacteria [6] so that it can remodel complex compounds into simpler compounds in the form of lactic acid [4]. Lactic acid produced by L. Plantarum 1UHCC can break the double bonds of collagen into gelatin[24].

The presence of lactic acid produced by $L$. plantarum BAL on MRS-Broth media that has been added to goat skin ensures that the BAL L. plantarum bacteria can grow well. [14] Although its growth is unpredictable.

The purpose of this study was to see the ability to grow and the content of lactic acid produced by $L$. plantarum in the process of denaturing goatskin protein so that it easily produces gelatin.

\section{MATERIALS AND METHODS}

This research was conducted at the Microbiology Laboratory, Department of Biology, Faculty of Mathematics and Natural Sciences, Hasanuddin University Makassar. The material used is Ettawah male goat skin obtained on the same farm (1 year, 2 years and 3 years), which has been cleaned from fur and fat, L. plantarum 1 UHCC bacteria as a starter isolated from milkfish, MRS-broth and aquades. For making $300 \mathrm{ml}$ growth media, 15 $\mathrm{ml}$ of 24-hour cell suspension was carried out in MRS-broth medium into $285 \mathrm{ml}$ of MRSbroth media in each sample and carried out in laminar air flow.

$200 \mathrm{~g}$ goat skin raw material fermented using $L$. plantarum 1UHCC culture $5 \%$ concentration added with goat skin and bones into MRS-broth media (1:3b/v) using erlenmeyer covered with gauze and then dishaker for 24 hours, 48 hours and 72 hours at $28^{\circ} \mathrm{C}$.

The ability to grow L. plantarum bacteria by observing the total parameters of the bacterial population using the Petri dish method [3] using de Man Ragosa Sharpe agar (MRSagar) media and calculated using the number of plates. Observation of Lactic Acid Level Titration method [2], determined by titration using $0.1 \mathrm{~N} \mathrm{NaOH}$ solution, and $\mathrm{PP}$ (phenolpthalein). The $\mathrm{pH}$ is carried out using a potentiometric method that uses a $\mathrm{pH}$ meter that was previously calibrated using a buffer solution of $\mathrm{pH} 4$ and $\mathrm{pH}$ 7. Dissolved Protein levels are determined by the Lowry method [20] by adding lowry A (Follin-Ciocalteus and 1: 1 distilled water), lawry $\mathrm{B}(\mathrm{Na} 2 \mathrm{CO} 32 \%$ / $\mathrm{NaOH} 0.1 \mathrm{~N}, 1 \% \mathrm{CuSO} 4$, Na-Tartrate $1 \%$ ratio 100: 1: 1) in all experimental units. The data obtained were processed using SPSS version 21 , a completely randomized design (CRD) $3 \times 3$ factorial pattern. treatment of goat age and goat fermentation time. The age factor of goat skin a1 $=1$ year, $\mathrm{a} 2=2$ years, $\mathrm{a} 3=3$ years and fermentation time factor $\mathrm{b} 1=24$ hours, $\mathrm{b} 2=48$ hours and b3 $=72$ hours. Each treatment was repeated 4 times.

\section{RESULTS AND DISCUSSION}

The ability to grow L. plantarum bacteria on different age goat skins through the calculation of the total population of bacteria and their metabolic results, including measurement of lactic acid, $\mathrm{pH}$ and dissolved protein levels formed during the fermentation process can be seen in table 1. 
Table 1. Changes in population Total Bacteria, Lactic Acid Levels, $\mathrm{pH}$ and Protein Levels Dissolved in Goat Skin with the Age of Goats and Different Fermentation Times

\begin{tabular}{|c|c|c|c|c|c|}
\hline \multirow{2}{*}{ Variable } & \multirow{2}{*}{$\begin{array}{c}\text { Goat age } \\
\text { (year) }\end{array}$} & \multicolumn{3}{|c|}{ Duration of Fermentation (hour) } & \multirow{2}{*}{ Mean \pm SD } \\
\hline & & 24 & 48 & 72 & \\
\hline \multirow[t]{4}{*}{ Total bacteria } & 1 & $8.42 \pm 0.48$ & $8.81 \pm 0.37$ & $9.11 \pm 1.29$ & $8.78 \pm 0.52$ \\
\hline & 2 & $8.40 \pm 0.36$ & $8.77 \pm 0.35$ & $9.26 \pm 0.82$ & $8.81 \pm 0.61$ \\
\hline & 3 & $8.68 \pm 0.56$ & $8.86 \pm 0.60$ & $9.65 \pm 0.18$ & $9.06 \pm 0.68$ \\
\hline & Mean \pm SD & $8.50 \pm 0.45^{\mathrm{a}}$ & $8.81 \pm 0.41^{\mathrm{ab}}$ & $9.34 \pm 0.70^{b}$ & \\
\hline \multirow[t]{4}{*}{ Lactic acid } & 1 & $1.01 \pm 0.01$ & $0.96 \pm 0.10$ & $1.07 \pm 0.03$ & $\mathbf{1 . 0 1} \pm \mathbf{0 . 0 7}$ \\
\hline & 2 & $0.98 \pm 0.11$ & $0.79 \pm 0.14$ & $1.03 \pm 0.05$ & $0.93 \pm 0.14$ \\
\hline & 3 & $1.11 \pm 0.28$ & $0.83 \pm 0.12$ & $1.05 \pm 0.02$ & $0.99 \pm 0.20$ \\
\hline & Mean \pm SD & $1.03 \pm 0.17^{\mathrm{a}}$ & $0.86 \pm 0.14^{b}$ & $1.05 \pm 0.04^{b}$ & \\
\hline \multirow[t]{4}{*}{$\mathrm{pH}$} & 1 & $5.53 \pm 0.37$ & $5.48 \pm 0.35$ & $5.31 \pm 0.27$ & $5.44 \pm 0.37^{\mathrm{a}}$ \\
\hline & 2 & $5.59 \pm 0.20$ & $5.60 \pm 0.08$ & $5.58 \pm 0.23$ & $5.60 \pm 0.16^{\mathrm{ab}}$ \\
\hline & 3 & $5.49 \pm 0.31$ & $5.63 \pm 0.41$ & $5.76 \pm 0.06$ & $5.63 \pm 0.26^{\mathrm{a}}$ \\
\hline & Mean \pm SD & $5.54 \pm 0.36$ & $5.57 \pm 0.28$ & $5.55 \pm 0.27$ & \\
\hline Dissolved & 1 & $7.42 \pm 0.21$ & $8.65 \pm 0.17$ & $9.64 \pm 0.26$ & $8.57 \pm 0.97^{a}$ \\
\hline \multirow[t]{3}{*}{ Protein } & 2 & $7.29 \pm 0.30$ & $8.22 \pm 0.19$ & $8.38 \pm 0.35$ & $7.96 \pm 0.57^{a}$ \\
\hline & 3 & $7.54 \pm 0.26$ & $8.31 \pm 0.31$ & $8.38 \pm 0.07$ & $8.08 \pm 0.45^{b}$ \\
\hline & Mean \pm SD & $7.42 \pm 0.26^{\mathrm{a}}$ & $8.40 \pm 0.29^{b}$ & $8.80 \pm 0.66^{c}$ & \\
\hline
\end{tabular}

Note: Different superscripts in the same row and column show significant differences $(\mathrm{P}<0.05)$ and $(\mathrm{P}<0.01)$ SD: Standart Deviation

\subsection{Total Bacteria}

Based on table 1 shows Age of goats did not show a significant effect $(\mathrm{P}>0.05)$ on total bacteria and there were no differences between ages 1, 2 and 3 years, but that the bacterial population experienced a fairly rapid growth and a significant $(\mathrm{P}<0.05)$ increase in the duration of fermentation 24 hours. 48 hours to 72 hours. the number of cells ranged $8.50 \pm 0.45 \mathrm{a} \quad \log _{10} \mathrm{CFU} / \mathrm{mL}$. $8.81 \pm 0.41 \mathrm{ab} \quad \log _{10}$ $\mathrm{CFU} / \mathrm{mL}$. $\quad 9.34 \pm 0.70 \mathrm{~b} \quad \log _{10} \mathrm{CFU} / \mathrm{mL}$. This shows that every microbial cell can synthesize simple substances found in its environment for its growth[15]. total L. plantarum bacteria on goat skin compared to[4] total L. plantarum bacteria growing on egg white for fermentation time of 18 hours. 24 hours and 30 hours of fermentation respectively $5.884 \pm 0.157$ $\log _{10} \mathrm{CFU} / \mathrm{ml} ; \quad 6.035 \pm 0.024 \quad \log _{10} \mathrm{CFU} / \mathrm{ml}$; $6.131 \pm 0.095 \log _{10} \mathrm{CFU} / \mathrm{ml}$.
The difference in the total population of $L$. plantarum bacteria is determined on the fermentation time. [4] The longer the fermentation time (72 hours) the growth of $L$. plantarum bacteria increases. This is in line with research [15] L. plantarum coupled with silage growth from L. plantarum increased to $99.13 \%$ on day 3 (72 hours). [3] Suitable environments including the availability of adequate nutrition will increase bacterial productivity during fermentation thereby affecting the amount of microbes produced[21].

\subsection{Lactic Acid}

Table 1 shows the age of the goat did not show a significant effect on lactic acid, however lactic acid experienced a significant $(\mathrm{P}<0.05)$ increase in the duration of 24 hour for fermentation to 72 hours ranging from $1.03 \pm 0.17 \mathrm{a} \% ; 1.05 \pm 0.04 \mathrm{~b} \%$ but experienced a 
decrease in lactic acid production at 48 hours $0.86 \pm 0.14 \mathrm{~b} \%$. [7] The lactic acid produced is not much different from the 60 hour fermentation of fermented solid substrate using grated cassava media added by $L$. plantarum UA3 of $0.92 \%$. This is because L. plantarum is able to convert complex compounds into simpler compounds producing lactic acid. Lactic acid can produce a low $\mathrm{pH}$ on the substrate causing a sour atmosphere. $L$. plantarum can increase acidity by $1.5 \%$ to $2 \%$ on the substrate. In acidic conditions $L$. plantarum has the ability to inhibit pathogenic bacteria [6].

Lactic acid values at 48 hours of fermentation decreased. It is estimated that in the 48-hour fermentation the nutrients contained have begun to decrease so that $L$. plantarum utilizes the surrounding environment to convert protein compounds into simpler compounds. This is in accordance with the opinion [17] L. plantarum is a type of proteolytic bacteria that is able to convert protein compounds into simpler compounds such as lactic acid. so the production of lactic acid is not only the result of carbohydrate improvement but from the re-formation of glycoprotein contained in goat skin.

\section{3.pH}

Table 1. Shows a significant $(\mathrm{P}<0.05)$ effect on the age of goat skin. $\mathrm{pH}$ at 1 year of age 5.44 \pm 0.37 tending to be acidic compared to age 2 years $5.60 \pm 0.16$ and 3 years $5.60 \pm 0.26$. Decrease in $\mathrm{pH}$ value is higher than the study [4] which shows the length of fermentation of egg whites with $L$. plantarum 18 hours, 24 hours and 30 hours respectively $7.689 \pm 0.035$; $6.434 \pm 0.501 ; 6.353 \pm 0.65$. [21] increasing the fermentation time results in a decrease in the $\mathrm{pH}$ value in the fermentation of egg whites.

The 1 year skin $\mathrm{pH}$ showed the highest acidity. although the fermentation time does not show a significant effect. Allegedly 1 year old goat skin is solid connective tissue so that L.plantarum is easier to degrade glycoprotein to produce lactic acid which is characterized by a decrease in $\mathrm{pH}$. [7] states that the production of lactic acid by $L$. plantarum affects the decrease in $\mathrm{pH}$. research [17] showed the ability of $L$. plantarum to reduce $\mathrm{pH}$ to inhibit the growth of aflatoxin production of Aspergillus flavus (AFL) by $91 \%$. The decrease in $\mathrm{pH}$ is one result of the fermentation process that occurs due to the accumulation of lactic acid and organic acids[23].

\subsection{Dissolved protein}

The dissolved protein showed a very significant effect $(P<0.01)$ on the age of the goat and the duration of fermentation, the longer the fermentation ( 72 hours), the more protein was dissolved $(8.80 \pm 0.66 \% \mathrm{~g} / \mathrm{mL})$, but the lower the age of the goat (1 year) dissolved protein increases $(8.57 \pm 0.97 \% \mathrm{~g} / \mathrm{mL})$. the duration of fermentation is 24 hours to 48 hours and 72 hours has increased. Soluble proteins vary depending on $\mathrm{pH}$ and the composition of amino acid residues [12]. Proteins in principle have maximum uptake due to the presence of peptide bonds [5].

Some of the previous researches included [11], there were reports that the fermented tofu content using $L$. plantarum protein value was $8.66 \%$. The resulting lactic acid decreases the $\mathrm{pH}$ value of its growth environment [16] under these conditions, dissolved proteins are hydrolyzed into amino acids so that the dissolved protein content in the sample increases. [8] reported that the use of lactic acid bacteria in the fermentation process can increase food palatability and improve food quality by increasing the availability of protein and vitamins. [13] So the longer the time is used, the higher the level of dissolved protein from the goat skin produced.

\section{CONCLUSION}

The most effective growth ability of $L$. plantarum was obtained at 72 hours fermentation time. along with increased production of lactic acid and dissolved protein in goat skin. The age of 1 year goats shows better quality than skin 1 and 2 years to be used as curing material in gelatin making by looking at the variable $\mathrm{pH}$ which decreases and dissolved protein increases. 


\section{ACKNOWLEDGMENT}

The authors would like to thank the hasanuddin university postgraduate and to (LPDP) the finance ministry of the Republic of Indonesia for BUDI-DN awardee research funding facilities with LPDP 'PRJ517/LPDP.4/2019' contract numbers ID Number: 20161141030463.

\section{REFERENCES}

[1] Hasma, Abustam E, Said MI 2016 Kualitas Bakso Daging Kerbau dengan Penambahan Gelatin Terhidrasi pada Rasio dan Level berbeda Selama Penyimpanan. Buletin Peternakan Media Informasi dan komunikasi. 1 5159

[2] AOAC International 2000 Official Methods of Analysis of AOAC International. Gaitherburg. USA.

[3] Irianto K 2010 Mikrobiologi Menguak Dunia Mikroorganisme. Yrama Widya. Bandung.

[4] Nahariah, Legowo AM, Abustam E, Hintono A, Pramono YB dan Yuliati FN 2013 Kemampuan tumbuh bakteri Lactobacillus plantarum pada putih telur ayam ras dengan lama fermentasi yang berbeda JITP 3 33-39.

[5] Stanbury PF, Whitaker A, and Hall SJ 2003 Principles of Fermentation Technology. Butterworth Heinemann, Oxford.

[6] Puspadewi R, Putranti A, Gina A 2011 Aktivitas Metabolit Bakteri Lactobacillus plantarum dan Perannya dalam Menjaga Kesehatan Saluran Pencernaan. Konferensi Nasional Sains dan Aplikasinya. 1 1-10

[7] Zulafa N, Cahyanto MN, Retno I, Sardjono S 2017 Screening of Lactobacillus plantarum producing lactic acid for mocaf fermentation. Agritech. 37 437-442

[8] Chelule PK, Mokoena MP dan Galeni N 2010 Advantages of traditional lactic acid bacteria fermentation of food in Africa. Current Research, Technology and Education Topics in Applied
Microbiology and Microbial Biothecnology 2 1160-1167.

[9] Kolodziejska I, Skierka E, Sadowska $\mathrm{M}$, Kolodziejski $\mathrm{W}$ and Niecikowska $\mathrm{C}$ 2008 Effect of extracting time and temperature on yield of gelatin from different fish offal. Food Chem. 107 700-706.

[10] Purwanto MG 2014 Jurnal Ilmiah Sain \& Teknologi. Lembaga Penelitian dan Pengabdian kepada Masyarakat Universitas Surabaya. 7 64-71

[11] Noor, and Dilla TF. 2012 Chocolate Cookies, Bulan Sabit Cookies, dan Pie Lemon Cookies. Proyek Akhir. Yogyakarta. Universitas Negeri Yogyakarta.

[12] Aini N, Wijonarko G, Sustriawan B 2016 Physical, Chemical, and Functional Properties of Corn Flour Processed by Fermentation. Agritec. 36 160-169

[13] Aruni F, Dwitasari I, dan Gunawan S 2014 Pengaruh Waktu Fermentasi Menggunakan lactobacillus plantarum terhadap Kandungan Protein pada Tepung Mosof (Modified Sorghum Flour). Jurnal Teknik Pomits. 3 160-162

[14] Mugampoza D, Gkatzionis K, Linforth, RST, Dodd, CER 2019 Acid production, growth kinetics and aroma profiles of Lactobacillus flora from Stilton cheese. Food Chemistry. 82 1-36

[15] Yang, L, Yuan X, Li J, Dong Z, Shao T 2018 Dynamics of microbial community and fermentation quality during ensiling of sterile and nonsterile alfalfa with or without Lactobacillus plantarum inoculant. Bioresource Technology. 67 1-34

[16] Guimaraes A, Santiago A, Teixeira JA, Venancio A, Abrunhosa L 2017 Antiaflatoxigenic effect of organic acids produced by Lactobacillus plantarum. Food 25 1-30

[17] Hong WM, Xiao-Bin Fang, Tong Wu, Li Fang, Chun-Lei Liu, and Ji Wang 2018 Characterization and antioxidant activity of an acidic exopolysaccharide from Lactobacillus plantarum JLAU103. 
Journal of Bioscience and Bioengineering. 4 1-9

[18] Said MI, Likadja JC, Hatta M 2011 Pengaruh Waktu Dan Konsentrasi Bahan Curing Terhadap Kuantitas Dan Kualitas Gelatin Kulit Kambing Yang Diproduksi Melalui Proses Asam. JITP. 1 1-10

[19] Ockerman, HW and Hansen, C.L 2000 Animal by Product Processing and Utilibahanion. CRC Press. Florida. USA

[20] Wikandari PR., Suparmo Y, Marsono, Rahayu ES 2011 Potensi bekasem sebagai Sumber Angiotensin Iconverting Enzyme Inhibitory. Biota. 16 145-152.

[21] Nahariah, Hikmah H, Yuliati F N 2018 Microbiological activities in fermented egg whites with different level of milk and fermentation times. 1st International
Conference of Animal Science and Technology (ICAST). Earth and Environmental Science 247 1-4

[22] Said MI, Suharjono T, Erwanto Y 2014 Aplikasi gelatin kulit kambing blogon sebagai bahan dasar dalam formula terhadap sifat-sifat cangkang kapsul obat. JIIP, 1(2), 150-157

[23] Usman NA, Suradi K, Gumilar J 2018 Pengaruh konsentrasi bakteri asam laktat Lactobacillus plantarum dan lactobacillus casei terhadap mutu mikrobiologi dan kimia mayones probiotik. Jurnal Ilmu ternak, 18(2) 7985

[24] Hasma, Abustam E, Malaka R, Said M I, Nahariah N and Laga A 2020 Effectivenes of Lactobacillus plantarum 1UHCC Bacteria in Partial Hydrolysis of Goat Bone inProducing Gelatin IOP Conf. Ser.: Earth Environ. Sci.49212084 